\title{
Tissue Contrast Differentiation between Head and Neck Squamous Cell Carcinoma Tumors and Adjacent Tissues in Early and Late Phases by Multi-Slice CT Scan
}

\author{
Salahshoor A ${ }^{1}$, Hormozi-Moghaddam Z ${ }^{2}$, Shayesteh SP3 and Sharifian $\mathrm{H}^{4^{*}}$ \\ ${ }^{1}$ Department of Radiology, Faculty of Medical Science, Alborz university of Medical Science, Karaj, Iran \\ ${ }^{2}$ Department of Medical Physics, Faculty of Medical Sciences, Tarbiat Modares University, Tehran, Iran \\ ${ }^{3}$ Department of Physiology, Pharmacology and Medical Physics, Faculty of Medical Science, Alborz University of Medical Science, karaj, Iran \\ ${ }^{4}$ Department of Radiology, Faculty of Medical Science, Tehran University of Medical Science, Tehran, Iran
}

${ }^{*}$ Corresponding author: Dr. Hashem Sharifian, Radiologist, Department of Radiology, Faculty of Medical Science, Tehran University of Medical Science, Tehran, Iran, Tel: 9128480905; E-mail: Hashemsharifian@gmail.com

Received date: October 30, 2019; Accepted date: May 21, 2020; Published date: May 28, 2020

Citation: Salahshoor A, Hormozi-Moghaddam Z, Shayesteh SP, Sharifian H (2020) Tissue Contrast Differentiation between Head and Neck Squamous Cell Carcinoma Tumors and Adjacent Tissues in Early and Late Phases by Multi-Slice CT Scan. Arch Med Vol.12 Iss.3:11

Copyright: (2020 Salahshoor A, et al. This is an open-access article distributed under the terms of the Creative Commons Attribution License, which permits unrestricted use, distribution, and reproduction in any medium, provided the original author and source are credited.

\section{Abstract}

Background: Malignancies of head and neck are common cancers responsible for 6 percent of all malignancies. Use of multi-slice CT scan has led to shorter time of scan with optimal capacity in constant time. This study aimed to evaluate the tissue contrast differentiation between head and neck Squamous Cell Carcinoma tumors and adjacent muscle tissue in early and late phases by multi-slice CT scan.

Methods and materials: In this cross-sectional study, 76 patients with head and neck Squamous Cell Carcinoma referred to us in imaging center of Tehran Amir A'lam hospital in 2014-5015. Multi-slice CT scan were conducted at early time ( 20 seconds) and 180 and 300 seconds after contrast media injection. Then, Hounsfield score of affected tissue and nearest muscle was measured. $\Delta$ density was defined as the contrast between tumor density and nearest muscle density.

Results: The mean of tumor density at early phase, late phase (180s) and (300s) was 75/76 $\pm 21 / 08,75 / 26 \pm$ $12 / 96$ and $74 / 14 \pm 12 / 57$, respectively ( $P>0.05)$. Conversely, the muscle density significantly was lower in early phase compare to late phase $(65 / 31 \pm 11 / 65$ vs. $69 / 06 \pm 12 / 23$ and $69 / 82 \pm 10 / 69, \mathrm{P}<0.001)$. Our results also showed that $\Delta$ density was decreased in late phases, however, this reduction was not statistically significant $(\mathrm{P}=0.08)$.

Conclusion: Results indicated that multi-slice CT scan may have good tissue contrast differentiation ability between head and neck Squamous Cell Carcinoma tumors and adjacent muscle tissues in early phases after contrast media injection.
Keywords: Squamous cell carcinoma; Head and neck; Multi-slice CT scan; Tumor; Muscle

\section{Introduction}

Malignancies of head and neck are common cancers responsible for 6 percent of all malignancies with 600000 new cancers and 350000 deaths due to cancers annually [1]. These include oral, nasopharyngeal, oropharyngeal, laryngeal, and sinonasal cancers and are as Squamous Cell Carcinoma (SCC) in 95\% of cases [2,3]. Clinical symptoms, treatment, and prognosis are related to pathological type and grade [4] and 5year survival is nearly 60\% [5]. An epidemiologic study in 2016 in Iran showed that the incidence of head and neck cancers was 7.4 per 100,000 in 2009 [6].

Since early diagnosis can result in better prognosis, use of optimal imaging modalities would result in better outcomes. Use of multi-slice CT scan has led to shorter time of scan with optimal capacity in constant time $[7,8]$. Higher contrast in cervical vessels would result in higher resolution of images and higher quality $[7,9,10]$. Contrast-enhanced diagnostic CT is useful for approximation of head and neck cancer volumes [11]. It should be considered that Contrast enhancement at CT is affected by numerous interacting factors including patient, contrast medium, and CT scanning factors [11,12].

There are few studies about contrast increase in soft tissue, it has been reported various resolutions in early times $[13,14]$ and the importance of late phase is not yet clear. The more constant and homogeneous tissue in any part of the neck is muscular tissue and so it is logical we compare various tumors by the most nearby muscle, instead of other tissues in the neck. In paranasal sinuses native contrast of the air and soft tissues make differentiation of tissues easier and so we did not enter any paranasal sinus SCC in our study. In this study, we 
evaluated the tissue contrast differentiation between head and neck SCC tumors and adjacent muscle tissue in early and late phases by multi-slice CT scan.

\section{Material and Methods}

\section{Study population}

In this cross-sectional study, 76 patients with head and neck SCC referred to us in imaging center of Tehran Amir A'lam hospital in 2014-2015. The patients were diagnosed with pathological findings. The exclusion criteria were pregnancy and also contraindication for contrast use. Four cases with benign pathology or other malignancies were excluded. Also two cases had more than one mass which were considered as two separate cases to increase the number of them. The study protocol was approved by the ethics committee of Tehran University of Medical Sciences and all participants were informed before taking part in the study.

\section{Multi-slice CT scan}

Early and late indices in multi-slice CT scan were conducted by Siemens Co. (Emotion 16 Slice model) with dual phase model. Hounsfield score of affected tissue and nearest muscle was measured at early time (20 seconds) and 180 and 300 seconds after injection. For each 1.5 centimeter one region of interest (ROI) was considered and the mean ROI was calculated. The contrast differentiation potency was determined and compared between SCC tumors and surrounding muscle tissue. The early phase of scan was performed 20 seconds from initiation of contrast injection. Delta $(\Delta)$ density was defined as the contrast between tumor density and nearest muscle density.

\section{Statistical analysis}

In this study, we used the software SPSS 25 package (SPSS Inc, Chicago, IL) for data analysis and statistical calculation. The normal distribution of the numerical variables of patients was assessed using Kolmogorov-Smirnov Z-test. Friedman and Wilcoxon signed-rank tests were used to compare delta $\Delta$ density between three and two phases, respectively. P-value was considered as statistical significant when $\mathrm{P}$ was below 0.05 .

\section{Results}

The mean age of patients was $58.89 \pm 16.48$ years and $81.5 \%$ of them were male. $61.8 \%$ of patients were smoker. Clinical and demographic characteristics of the patients are summarized in Table 1 . The mean of tumor density at early phase, late phase (180s) and late phase (300s) was 75/76 \pm $21 / 08,75 / 26 \pm 12 / 96$ and $74 / 14 \pm 12 / 57$, respectively. Our analysis showed lack of significant difference between three time interval regard to tumor density (Table 2, Figure 1A). Conversely, the muscle density significantly was lower in early phase compare to late phase $(65 / 31 \pm 11 / 65$ vs. $69 / 06 \pm 12 / 23$ and $69 / 82 \pm 10 / 69, \mathrm{P}<0.001$, Table 2, Figure 1B). Our results also showed that delta $(\Delta)$ density was decreased in late phases, however, this reduction was not statistically significant $(\mathrm{P}=0.08$, Table 2, Figure $1 \mathrm{C})$.

Table 1 Clinical and demographic features of SCC patients.

\begin{tabular}{|l|l|}
\hline Characteristics & SSC patients \\
\hline Number of subjects & 76 \\
\hline Gender & $62 / 14$ \\
\hline Age (Mean \pm SD)(years) & $58.89 \pm 16.48$ \\
\hline Smoker (Yes/No) & $47 / 29$ \\
\hline
\end{tabular}

Table 2 Tumor density, nearest muscle density and $\Delta$ density at different phases.

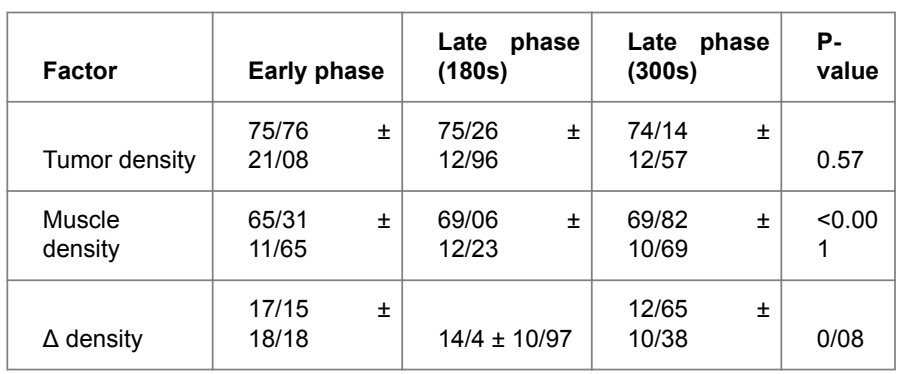

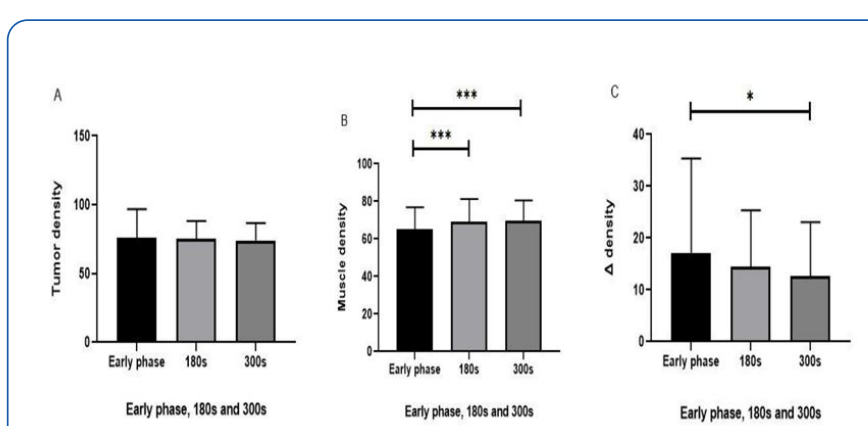

Figure 1 Comparison of tumor density (A), muscle density (B) and $\Delta$ density at different phases. The density was determined by multi-slice CT scan. Statistical significant was set at $\mathrm{P}<0.05$ (C).

\section{Discussion}

In this study, the tissue contrast differentiation between head and neck SCC tumors and adjacent muscle tissues was determined in early and late phases by multi-slice CT scan. It was seen that tumor adjacent muscle had better resolution in late phases that early phases and tumor density and tissue differentiation contrast ( $\Delta$ density) had no significant changes. In this era some similar studies are compared in next paragraphs, but in the past we have not comparison of tissue contrast in relation to muscles as a potential tool for better visualization of tumor extension which it is our goal in this study.

Groell et al. [15] reported that early scans are better for helical CT studies of the head and neck, but delayed scans may 
improve lesion detection in patients with SCC of head and neck. Similar to Groell et al.'s study, we observed that tumor adjacent muscle conspicuity significantly was better in late phases, whereas, tumor density and were not significantly difference between early and late phases.

Conrad et al. [13] demonstrated that in $58 \%$ of patients with pharyngeal or laryngeal carcinoma, early scans are better for detection of squamous cell carcinomas in the pharynx and larynx. A Study by Keberle and his colleagues [16] assessed the time of best contrast of neck malignancies in contrastenhanced CT in 20 patients with SCC of head and neck and showed an optimal tumor contrast and a good contrast between lymph nodes and neck vessels or muscle between 50 and $75 \mathrm{~s}$ after starting the injection. The discrepancy between us and similar studies may be in part due to different study protocol. Joshi et al. reported that among different imaging modalities for head and neck SCC tumors, the multi-slice CT scan had good tissue contrast ability and are useful for treatment decision-making. This matter was also seen in our study for early phase [17].

Hadjiiski et al. [18] reported that multi-slice CT scan may be used at early phase for differentiation of tumor parts with therapeutic response as well difference seen in our study. Schmitz and colleagues [19] reported that multi-slice CT scan may be used at early phase for treatment response monitoring. Also Hwang et al. [12] reported that it may be used for determination of recurrence which is in congruence with our results in current study.

\section{Conclusion}

Taken to gather, it may be concluded that multi-slice CT scan may have good tissue contrast differentiation ability between head and neck SCC tumors and adjacent muscle tissues in early and late phases after contrast media injection with higher ability at early phase which is lowered at late phase and there is no difference between two late phases. However, further studies with larger sample size and assessment of other modalities for head and neck SCC tumors are recommended to be performed.

\section{Conflict of Interest}

The authors declare that there is no conflict of interests.

\section{Acknowledgement}

The authors thank of patients for their participant in this study.

\section{Limitations}

There was no limitation of the study.

\section{References}

1. Jemal A, Bray F, Center MM, Ferlay J, Ward E (2011) Global cancer statistics. CA Cancer J Clin. 61: 69-90.
2. Abgral R, Querellou S, Potard G, Le Roux PY, Le Duc-Pennec A, et al. (2009) Does 18F-FDG PET/CT improve the detection of posttreatment recurrence of head and neck squamous cell carcinoma in patients negative for disease on clinical follow-up? J Nucl Med. 50: 24-29.

3. Daley T, Darling M (2003) Nonsquamous cell malignant tumours of the oral cavity: An overview. Journal (Canadian Dental Association). 69: 577-582.

4. Imsande HM, Davison JM, Truong MT, Devaiah AK, Mercier GA, et al. (2011) Use of 18F-FDG PET/CT as a predictive biomarker of outcome in patients with head-and-neck non-squamous cell carcinoma. AJR Am J Roentgenol. 197: 976-980.

5. Moeller BJ, Rana V, Cannon BA, Williams MD, Sturgis EM, et al. (2009) Prospective risk-adjusted [18F] Fluorodeoxyglucose positron emission tomography and computed tomography assessment of radiation response in head and neck cancer. Journal of clinical oncology: official journal of the American Society of Clinical Oncology. 27: 2509-2515.

6. Mirzaei M, Hosseini SA, Ghoncheh M, Soheilipour F, Soltani S, et al. (2015) Epidemiology and trend of head and neck cancers in Iran. Glob J Health Sci. 8: 189-193.

7. Spreer J, Krahe T, Jung G, Lackner K (1995) Spiral versus conventional CT in routine examinations of the neck. Journal of computer assisted tomography. 19: 905-910.

8. Suojanen JN, Mukherji SK, Dupuy DE, Takahashi JH, Costello P (1992) Spiral CT in evaluation of head and neck lesions: work in progress. Radiology. 183: 281-283.

9. Yoon DY, Chang KH, Han MH, Kim HD, Kim SH, et al. (1997) Reevaluation of optimal dose of contrast medium for vascular enhancement in CT of the head and neck. Neuroradiology. 39: 30-34.

10. Groell R, Willfurth P, Schaffler GJ, Mayer R, Schmidt F, et al. (1999) Contrast-enhanced spiral CT of the head and neck: comparison of contrast material injection rates. AJNR Am J Neuroradiol. 20: 1732-1736.

11. Lee JH, Ryu CW, Kim SM, Kim EJ, Choi WS (2012) Usefulness of biphasic contrast injection in multidetector CT of the head and neck: A comparison with monophasic contrast injection. J Korean Soc Radiol. 67: 85-92.

12. Hwang HJ, Kim MY, Kim SS, Choi CM (2015) CT Characteristic of Early Local Recurrence After Resection of the Squamous Cell Carcinoma: Comparison With CT Characteristics of Stump Deformity or Granulation Tissue at Stump Site. Medicine. 94: e1691.

13. Conrad R, Pauleit D, Layer G, Kandyba J, Kohlbecher R, et al. (1999) Spiral CT of the head-neck area: the advantages of the early arterial phase in the detection of squamous-cell carcinomas. Rofo. 171: 15-19.

14. Harris EW, LaMarca AJ, Kondroski EM, Murtagh FR, Clark RA (1996) Enhanced CT of the neck: improved visualization of lesions with delayed imaging. AJR Am J Roentgenol. 167: 1057-1058.

15. Groell R, Doerfler O, Schaffler GJ, Habermann W (2001) Contrast-enhanced helical CT of the head and neck: improved conspicuity of squamous cell carcinoma on delayed scans. AJR Am J Roentgenol. 176: 1571-1575.

16. Keberle M, Tschammler A, Berning K, Hahn D (2001) Spiral CT of the neck: When do neck malignancies delineate best during contrast enhancement? Eur Radiol. 11: 1986-1990. 
17. Joshi VM, Wadhwa V, Mukherji SK (2012) Imaging in laryngeal cancers. Indian J Radiol Imaging. 22: 209-226.

18. Hadjiiski L, Mukherji SK, Ibrahim M, Sahiner B, Gujar SK, et al. (2010) Head and neck cancers on CT: preliminary study of treatment response assessment based on computerized volume analysis. AJR Am J Roentgenol. 194: 1083-1089.
19. Schmitz S, Rommel D, Michoux N, Lhommel R, Hanin FX, et al. (2015) Dynamic contrast-enhanced computed tomography to assess early activity of cetuximab in squamous cell carcinoma of the head and neck. Radiol Oncol. 49: 17-25. 